\title{
EFFECT OF DIFFERENT N NUTRIENT CONTENTS ON BIOMASS OF GREEN MANURE AS SECOND CROP, UNDER UNFAVORABLE CLIMATE CONDITIONS IN HUNGARY
}

\author{
Mikó, P. ${ }^{*}$ - KovÁCS, G. P. - PERCZE, A. - GYURICZA, CS. \\ Szent István University, Institute of Crop Production \\ H-2103 Gödöllö, Páter K. u. 1. \\ (phone: +36-28-522-000/1668; fax: +36-28-410-804) \\ *Corresponding author \\ e-mail:Miko.Peter@mkk.szie.hu \\ (Received $2^{\text {nd }}$ Mar 2015; accepted $2^{\text {nd }}$ Feb 2016)
}

\begin{abstract}
The growth and nutrient composition of three plant species produced as second crop for green manure purposes (phacelia - Phacelia tanacetifolia Benth., mustard - Sinapis alba L. and oilseed radish Raphanus sativus L. var. oleiformis Pers.) were studied between 2007 and 2011 at the Crop Production and Biomass Utilisation Demonstration Centre (Növénytermesztési és Biomassza-hasznosítási Bemutató Központ) of Szent István University under unfavourable site conditions on Luvic Kastanozems soil (WRB 2014), subject to two different levels of fertiliser supply (0 kg/ha N; $50 \mathrm{~kg} / \mathrm{ha} \mathrm{N})$.

The application of $50 \mathrm{~kg} / \mathrm{ha}$ nitrogen active ingredient multiplied the biomass of each of the three plant species - as an average of the five years of the study to 2.86, 3.07 times and 2.51 times the amount produced without treatment, in the case of phacelia, mustard and oilseed radish, respectively. The rates of the increase of the dry matter content were somewhat lower than those of the green mass increase because the nitrogen improved supply also resulted in an increase in the water content of the green manure plants. One kilogram per hectare added nitrogen increased the green mass and the dry matter content by $412.5 \mathrm{~kg}$ and by $37.9 \mathrm{~kg}$ as an average of the five years of the study in the case of phacelia, while in the case of mustard the green mass and the dry matter content increased by $431.4 \mathrm{~kg}$ and $59.1 \mathrm{~kg}$, respectively. In the case of oilseed radish the corresponding figures were $386.7 \mathrm{~kg}$ and $34.1 \mathrm{~kg}$, respectively. Without added nitrogen however, the generally acceptable $10 \mathrm{t} / \mathrm{ha}$ biomass could not always be harvested from the given site of relatively unfavourable conditions.

The amount of NPK absorbed per hectare also increased in response to the added nitrogen - to 2.60/2.36/2.13 times the in the case of phacelia over 2007-2011, 2.81/2.29/2.29 times in the case of mustard and 2.72/2.09/1.95 times in the case of oilseed radish. Each kilogram of added nitrogen enabled the uptake of an added amount of $1.6 \mathrm{~kg}, 2.3 \mathrm{~kg}$ and $1.8 \mathrm{~kg}$ of additional nitrogen in the case of phacelia, mustard and oilseed radish, respectively, as an average of the period between 2007 and 2011. The nitrogen applied made a significant contribution to the uptake of phosphorous and potassium as well. Each kilogram of added nitrogen increased the uptake of $\mathrm{P}_{2} \mathrm{O}_{5}$ by $0.5 \mathrm{~kg} .0 .5 \mathrm{~kg}$ and $0.6 \mathrm{~kg}$ in the case of phacelia, mustard and oilseed radish, respectively and it boosted the uptake of $\mathrm{K}_{2} \mathrm{O}$ by $1.8 \mathrm{~kg}, 2.1 \mathrm{~kg}$ and $1.4 \mathrm{~kg}$ in the case of phacelia, mustard and oilseed radish, respectively.

It may be concluded from the above results that when a second crop is grown for use as green manure at the given cropping site the application of nitrogen is always recommended, to the extent possible, but if the straw is left on the soil surface after cereals, it is definitely strongly recommended.
\end{abstract}

Keywords: application of green manure, green manure crops, phacelia, mustard, oilseed radish, $N$ nutrient content

\section{Introduction}

Green manure plants are fresh green, non-woody plants, rich in water, sugar, starches, protein and nitrogen, worked into the soil (Kahnt, 1981). In analysing the effects of green manure plants on the next crop Kahnt (1981) identified a total of 14 factors of relevance. Owing to the large number of factors the effectiveness of the use of 
green manure can only be assessed on the basis of precise information of the given site's parameters.

Mustard (Sinapis alba L.) and oilseed radish (Raphanus sativus L. var. oleiformis Pers.) (both belonging to the Brassicaceae family) are particularly suitable for these purposes. They play a major role in soil protection (Brown and Morra, 1995; Grossman, 1993; Boydston and Hang, 1995) and in controlling soil-borne pathogens (Papavizas, 1966; Papavizas and Lewis, 1971; Ramirez and Villapudua Munnecke, 1988; Muelchen et al., 1990; Mayton et al., 1996; Croft et al., 1993; Deng et al., 1993), including nematodes (Mojtahedi et al., 1991, 1993), and soil-borne insects that are harmful to crops (Brown et al., 1991).

The soil disinfecting effects are caused by root excretions and, after their incorporation in the soil, the compounds released during their decomposition, even in small concentrations (Bialy et al., 1990; Lazzeri et al., 1993; Williams et al., 1993). Consequently, they inhibit the germination of weed seeds, along with the initial growth of the seedlings (Gardner et al., 1990; Bradow, 1991; Vaughn and Boydston, 1997).

Such positive effects have been observed in relation to phacelia (Phacelia tanacetifolia Benth.) as well (Dhima et al., 2009).

Phacelia and mustard are even suitable for the remediation of soils contaminated with heavy metals (Kim et al., 2010; Foucault et al., 2013).

Green manure plants absorb nitrogen from the soil, preventing its leaching out of the soil (Martinez and Guiraud, 1990; Jackson et al., 1993). The C:N ratio in the soil after the incorporation of the green manure plant depends on when it is worked into the soil, the type, moisture content and temperature of the soil (Cadisch and Giller, 1997). These are some of the parameters on which it depends whether the impact on the next crop is positive (Derpsch et al., 1986; Catt et al., 1992; Thorup-Kristensen, 1993; Kara and Penezoglu, 2000; Zhang and Fang, 2007; Collins, 2007), neutral (Allison et al., 1998a, 1998b; Richards et al., 1996), or negative (Allison and Armstrong, 1992; Clark et al., 1997a, 1997b; Vaughan and Evanylo, 1998).

The most important characteristics of a good green manure plant include rapid growth, a large amount of biomass and inexpensive sowing seeds. The aim of our research was to examine the performance of three green manure plants possessing each of the above characteristics, under the given unfavourable cropping site conditions. We sought for answers also to whether successful application of green manure is possible even without added nitrogen, in view of the expected pentosan effect or whether the application of nitrogen is an indispensable prerequisite. The amount by which a unit of added nitrogen increased the amount of the green mass and the dry matter was also examined, along with the increase in the per-hectare NPK uptake.

\section{Material and methods}

The trials were set up in the town of Gödöllö, in the Crop Production and Biomass Utilisation Demonstration Centre of Szent István University $\left(47^{\circ} 34^{\prime} 43^{\prime \prime} \mathrm{N} ; 1^{\circ} 22^{\prime}\right.$ 39' E; $229 \mathrm{~m}$ above sea level). The experiment site is in a low hilly area, on a gentle north-western slope. The area is rather heterogeneous, comprising spots of varying degrees of erosion and sedimentation.

The annual mean temperature is $9.4^{\circ} \mathrm{C}$, the annual average amount of precipitation is $590 \mathrm{~mm}$. The average rainfall during the months of August to October that is the most important period for the second crop in a given year is $150 \mathrm{~mm}$. 
Crop-years 2007 and 2008 were of average pattern from the aspect of the second crop in those years, with $169.4 \mathrm{~mm}$ and $130.8 \mathrm{~mm}$ rainfall between August and October, respectively. 2009 and 2011 however, were dry years, with merely $32.0 \mathrm{~mm}$ and 30.0 $\mathrm{mm}$ rainfall during the growing season of the green manure plants grown as second crop. 2010 on the other hand, was a rather wet year with $198.6 \mathrm{~mm}$ rain during the months of August to October.

The site is located in the micro-region called Gödöllö Hilly Region. The hilly region is characterised by eroded carbonate soils that are typical of hilly regions, elevated to varying extents and broken up in a checker pattern. In the area around the town of Gödöllö upper Pannonian freshwater limestone and chalky clay (marl) are to be found on the surface at various spots among the loess, sand and slope clay settled on the upper Pannonian sandy clay and river sediment. The area elevated during the Pleistocene and a heavily fragmented hilly region with rather steep slopes developed where soil erosion and deflation have resulted in the redeposition of large amounts of materials. The soil in the experiment site is a rust-brown forest soil developed, for the most part, on sand (luvic calcic phaeozem) according to the Hungarian genetic soil classification system. The rust-brown forest soil subtype that has evolved on Tertiary sand and marl belongs to the Ramann's brown forest soil type. As a result of the degradation processes a slightly humic variant of a fertile layer of a medium depth has developed (Stefanovits, 1999a, 1999b; Füleky, 1999; Máté, 2005). The area is exposed to erosion and the soil is sensitive to compaction.

The key soil parameters of the experimental plot are set out in Tables 1-2. According to the standards laid down in the MÉM-NAK (the Crop Protection and Agricultural Chemistry Centre of the Ministry of Agriculture and Food) (MÉM, 1979) the soil contains a low level of $\mathrm{N}$, a very high level of $\mathrm{P}_{2} \mathrm{O}_{5}$ and a good supply of $\mathrm{K}_{2} \mathrm{O}$.

Table 1. The soil profile of the experimental site

\begin{tabular}{|c|c|}
\hline $\begin{array}{l}\text { Ap layer }(0-25 \\
\mathrm{cm})\end{array}$ & $\begin{array}{l}\text { Brown (10YR 3/3), fresh, loose, slightly structured soil } \\
\text { comprising predominantly small crumbs, densely } \\
\text { interwoven with root residues, with a high proportion of } \\
\text { sand but no chalk. Rich in earthworm channels. The } \\
\text { transition into the layer below is sharp, a straight line in the } \\
\text { soil profile. }\end{array}$ \\
\hline $\begin{array}{l}\mathrm{A}_{2} \text { layer }(25-40 \\
\mathrm{cm})\end{array}$ & $\begin{array}{l}\text { Brown (10YR } 3 / 3) \text {, humid, slightly compacted, moderately } \\
\text { structured, comprising small crumbs, interwoven with root } \\
\text { residues, with some earthworm channels, containing no } \\
\text { chalk. The transition into the accumulation (subsoil) layer is } \\
\text { gradual, showing a wavy line. }\end{array}$ \\
\hline $\begin{array}{l}\text { B layer } \\
\mathrm{cm})\end{array}$ & $\begin{array}{l}\text { Red-brown ( } 2.5 \text { YR } 3 / 6) \text {, humid, compacted, of a granular } \\
\text { structure, less densely interwoven with roots, loam. The } \\
\text { transition into the layer below is gradual, showing a wavy } \\
\text { line. }\end{array}$ \\
\hline $\begin{array}{l}\text { BC layer }(60-70 \\
\mathrm{cm})\end{array}$ & $\begin{array}{l}\text { Mixed colour (10YR } 3 / 3 \text { and } 10 \mathrm{YR} 7 / 4) \text {, fresh, slightly } \\
\text { compacted, a clay of no particular structure. The transition } \\
\text { into the layer below is gradual, showing a baggy pattern. }\end{array}$ \\
\hline $\begin{array}{l}\text { C layer }(70-100 \\
\mathrm{cm})\end{array}$ & $\begin{array}{l}\text { Light yellowish brown (10YR 7/4), dry, tightly packed, with } \\
\text { no structure, a silted clay. }\end{array}$ \\
\hline
\end{tabular}


Table 2. Important pedological data of experiment

\begin{tabular}{ccccccccc}
\hline $\begin{array}{c}\text { Genetic soil } \\
\text { level }\end{array}$ & $\begin{array}{c}\mathrm{pH} \\
\left(\mathrm{H}_{2} \mathrm{O}\right)\end{array}$ & $\begin{array}{c}\text { Arany-type } \\
\text { plasticity } \\
\text { index }\end{array}$ & $\begin{array}{c}\text { humus } \\
(\%)\end{array}$ & $\begin{array}{c}\mathrm{CaCO}_{3} \\
(\%)\end{array}$ & $\begin{array}{c}\text { total salt } \\
(\%)\end{array}$ & $\begin{array}{c}\text { total N } \\
\mathrm{mg} \mathrm{kg}^{-1}\end{array}$ & $\begin{array}{c}\mathrm{AL}^{-\mathrm{P}_{2} \mathrm{O}_{5}} \\
\mathrm{mg} \mathrm{kg}^{-1}\end{array}$ & $\begin{array}{c}\mathrm{AL}^{-\mathrm{K}_{2} \mathrm{O}} \\
\mathrm{mg} \mathrm{kg}^{-1}\end{array}$ \\
\hline $\mathrm{A}(0-40 \mathrm{~cm})$ & 6.76 & 30 & 1.32 & 0.00 & 0.044 & 16.8 & 371.1 & 184.0 \\
$\mathrm{~B}(40-60 \mathrm{~cm})$ & 7.08 & 40 & 1.04 & 0.00 & 0.052 & 11.9 & 33.0 & 112.0 \\
$\mathrm{BC}(60-70 \mathrm{~cm})$ & 7.66 & 61 & 0.88 & 0.00 & 0.060 & 2.0 & 123.0 & 127.1 \\
$\mathrm{C}(70-100 \mathrm{~cm})$ & 8.10 & 60 & 0.54 & 5.57 & 0.075 & 16.8 & 107.5 & 110.8 \\
\hline
\end{tabular}

The green manure experiments with the second crops were conducted in 2007-2011. The seeds of the plants grown as second crops in the experiments were sown after harvesting the previously grown winter wheat, where harvest was immediately followed by stubble stripping. In each year the second crop was sown right after stubble treatment, on 15 August split-plot experimental design. One plot size was $10 \mathrm{x} 100$ meters. Three plant species (phacelia - Phacelia tanacetifolia Benth., mustard - Sinapis alba L, oilseed radish - Raphanus sativus L. var. oleiformis Pers.) were grown and two different doses of nutrients $(0 \mathrm{~kg} / \mathrm{ha} \mathrm{N} ; 50 \mathrm{~kg} / \mathrm{ha} \mathrm{N})$ were applied in three iterations. Ammonium-nitrate was used as fertiliser, incorporated in the soil as part of stubble treatment. The seeds of the green manure plants were drilled in accordance with the sowing seed norms found in technical literature (Antal, 2000) (Table 3).

Table 3. The seeds requirement of green manure plants

\begin{tabular}{ccc}
\hline plants & germinal number ha ${ }^{-1}$ & seeds requirement $\left(\mathrm{kg} \mathrm{ha}^{-1}\right)$ \\
\hline phacelia & 5.000 .000 & 10 \\
mustard & 2.000 .000 & 15 \\
oilseed radish & 2.500 .000 & 25 \\
\hline
\end{tabular}

The biomass so produced was measured and samples for the analysis of chemical composition of the biomass were taken in early November before freezing of the vegetation.

The NPK content was established from $1 \mathrm{~g}$ finely ground absolute dry sample with sulphuric acid digestion and $30 \%$ hydrogen-peroxide thermal decomposition. After decomposition the N, P and K content was established from samples diluted up to 100 $\mathrm{cm}^{3}$. The nitrogen content was measured using a Parnass-Wagner water steam distiller apparatus.

The phosphorous content was measured using the vanadate-molybdate technique. The extinction of the yellow-colour solution was measured with a spectrophotometer (Spekol 221).

The potassium content was measured in the solutions used for the establishment of the phosphorous content as well, with a series of dilutions with a flame photometer (Jenway PFP 7).

The statistical evaluation was based on ANOVA test, one- and a two-factor variance analysis and post hoc tests. 


\section{Results and discussion}

The biomass of the green manure plants was heavily affected by the amount of precipitation (Table 4). The crop-year effect was particularly pronounced in the case of the plots where no fertiliser had been applied. Phacelia without fertiliser produced only $4.8 \mathrm{t} / \mathrm{ha}$ green mass in 2009, in contrast to the $20.3 \mathrm{t} / \mathrm{ha}$ produced in 2011 . Phacelia did not produce the minimum $10 \mathrm{t} / \mathrm{ha}$ green mass (Késmárki and Petróczki, 2003) without added nitrogen in 2008 and 2009. Nitrogen top dressing increased the green mass to 1.91-3.95 times - 2.85 times, as an average of five years - the amount produced without added nitrogen. Phacelia was hard hit by the drought of 2009, yet the application of nitrogen improved the plants' stress tolerance substantially, along with the efficiency of its utilisation of what little water there was, resulting ultimately in a $16.7 \mathrm{t} / \mathrm{h}$ green mass. The shortage of air in the soil, caused by the heavy rains in 2010 had a negative impact on the growth of the plants as well. This is considered to be the reason for the larger green mass produced in 2011. Similar results were also observed by BlazewickWozniak and Wach (2012).

In the case of mustard, the green mass produced without added nitrogen was below $10 \mathrm{t} / \mathrm{ha}$ only in 2008 and 2010 (7.3 t/ha and $7.7 \mathrm{t} / \mathrm{ha}$, respectively). The application of 50 $\mathrm{kg} / \mathrm{ha}$ nitrogen active ingredient boosted the amount of biomass produced to 3.07 times the amount produced without added nitrogen (that is, to $33.1 \mathrm{t} / \mathrm{ha}$ ), as an average of the 5 years of the experiment. The poor yield recorded in 2008 was caused by the drought, while in 2010 it was a result of the pentosan effect caused by the excessive rains.

Oilseed radish produced 9.8-22.5 t/ha biomass without and 27.6-43.4 t/ha with added fertiliser. Added nitrogen boosted the green mass produce to 1.93-3.33 times the amount produced without the application of fertiliser.

As an average of the five years of the experiment each of the three green manure plants produced similar amounts of biomass. Studies conducted by Stivers-Young (1998) however, showed that mustard and oilseed radish are capable of producing larger amounts of biomass than phacelia.

In terms of dry mass produced per hectare of land similar trends were observed to those found in regard to green mass, however, the increase in dry mass after the application of nitrogen fell short of the increase in green mass by $75.6 \%$ in the case of phacelia, $52.2 \%$ in the case of mustard and $54.3 \%$ in the case of oilseed radish, as an average of five years (Table 5). The reason for this was that the application of nitrogen resulted in an increase in the plants' water content as well. Phacelia, though the plants were not as tall as the mustard plants, produced as much or even more dry mass than the latter. Similar results were observed by Asagi and Ueno (2009) as well.

The nitrogen content per hectare increased after the application of nitrogen fertiliser to 2.6 times the amount found without added nitrogen in phacelia as an average of five years, from $57.3 \mathrm{~kg} / \mathrm{ha}$ to $136 / 1 \mathrm{~kg} / \mathrm{ha}$. The $50 \mathrm{~kg} / \mathrm{ha}$ nitrogen fertiliser enabled the uptake of an additional $28.8 \mathrm{~kg} / \mathrm{ha}$ of nitrogen (Table 6). Although Asagi and Ueno (2009) found that phacelia was capable of fixing as much nitrogen as mustard, our results showed that this is significantly affected by the so-called crop-year effect. Each of phacelia, mustard and oilseed radish was, however, capable of fixing $\mathrm{N}$ even at low temperatures (Stivers-Young, 1998). 
Table 4. The green mass of green manure plants ( $t$ ha $\left.{ }^{-1}\right)$ (Gödöllö, 2007-2011)

\begin{tabular}{|c|c|c|c|c|c|c|c|c|}
\hline treatments & & 2007 & 2008 & 2009 & 2010 & 2011 & mean & $\mathrm{LSD}_{5 \%}$ \\
\hline \multirow{4}{*}{ phacelia } & no fertilisation & $18.4 \pm 2.9 \mathrm{Ac}$ & $9,7 \pm 1.5 \mathrm{Ab}$ & $4,8 \pm 0.7 \mathrm{Aa}$ & $12,8 \pm 3.4 \mathrm{Abc}$ & $20,3 \pm 1.3 \mathrm{Ac}$ & 13,2 & 4.0 \\
\hline & with $50 \mathrm{~kg} \mathrm{~N} \mathrm{ha}^{-1}$ fertiliser & $35.2 \pm 2.3 \mathrm{Bb}$ & $38,5 \pm 4.8 \mathrm{Bbc}$ & $16,7 \pm 2.5 \mathrm{Ba}$ & $37,3 \pm 2.6 \mathrm{Bbc}$ & $41,5 \pm 1.4 \mathrm{Bc}$ & 33,8 & 5.3 \\
\hline & change in biomass $(\%)$ & $191 \%$ & $395 \%$ & $345 \%$ & $292 \%$ & $204 \%$ & $286 \%$ & \\
\hline & $\mathrm{LSD}_{5 \%}$ & 5.9 & 8.0 & 4.1 & 6.8 & 3.1 & & \\
\hline \multirow{4}{*}{ mustard } & no fertilisation & $12.9 \pm 2.8 \mathrm{Ab}$ & $7,3 \pm 2.5 \mathrm{Aa}$ & $16,6 \pm 3.8 \mathrm{Ab}$ & $7,7 \pm 2.4 \mathrm{Aa}$ & $13,3 \pm 1.1 \mathrm{Ab}$ & 11,6 & 4.8 \\
\hline & with $50 \mathrm{~kg} \mathrm{~N} \mathrm{ha}^{-1}$ fertiliser & $26.3 \pm 1.0 \mathrm{Ba}$ & $31,7 \pm 3.8 \mathrm{Ba}$ & $48,2 \pm 5.7 \mathrm{Bb}$ & $29,4 \pm 2.7 \mathrm{Ba}$ & $30,0 \pm 0.9 \mathrm{Ba}$ & 33,1 & 6.1 \\
\hline & change in biomass $(\%)$ & $204 \%$ & $433 \%$ & $291 \%$ & $383 \%$ & $225 \%$ & $307 \%$ & \\
\hline & $\mathrm{LSD}_{5 \%}$ & 4.7 & 7.3 & 11.0 & 5.7 & 2.3 & & \\
\hline \multirow{4}{*}{$\begin{array}{l}\text { oilseed } \\
\text { radish }\end{array}$} & no fertilisation & $13.9 \pm 1.0 \mathrm{Ab}$ & $9,8 \pm 0.5 \mathrm{Aa}$ & $10,3 \pm 2.4 \mathrm{Aa}$ & $13,6 \pm 1.6 \mathrm{Ab}$ & $22,5 \pm 1.2 \mathrm{Ac}$ & 14,0 & 2.7 \\
\hline & with $50 \mathrm{~kg} \mathrm{~N} \mathrm{ha}^{-1}$ fertiliser & $30.4 \pm 0.2 \mathrm{Bab}$ & $27,6 \pm 2.5 \mathrm{Ba}$ & $34,4 \pm 7.5 \mathrm{Bb}$ & $31,0 \pm 1.3 \mathrm{Bab}$ & $43,4 \pm 0.9 \mathrm{Bc}$ & 33,3 & 6.5 \\
\hline & change in biomass $(\%)$ & $219 \%$ & $282 \%$ & $333 \%$ & $228 \%$ & $193 \%$ & $251 \%$ & \\
\hline & $\mathrm{LSD}_{5 \%}$ & 1.6 & 4.1 & 12.6 & 3.2 & 2.4 & & \\
\hline
\end{tabular}


Table 5. The dry mass of green manure plants ( $\left.t \mathrm{~h}^{-1}\right)$ (Gödöllö, 2007-2011)

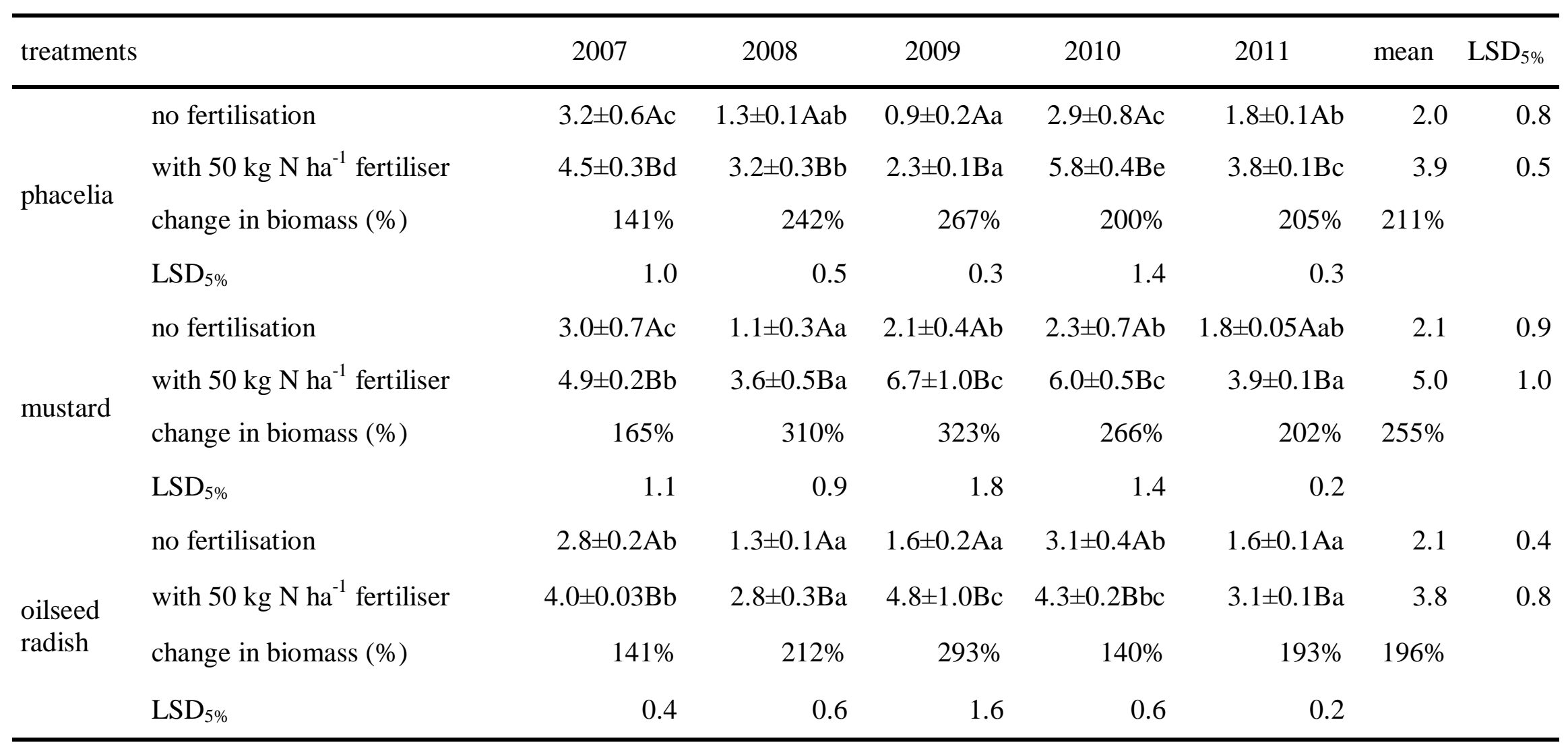


Table 6. Effect of different nutrient levels on the uptake of $N$ amount of green manure plants ( $\left.\mathrm{kg} \mathrm{ha}^{-1}\right)$ (Gödöllö, 2007-2011)

\begin{tabular}{|c|c|c|c|c|c|c|c|c|}
\hline treatment & & 2007 & 2008 & 2009 & 2010 & 2011 & mean & $\mathrm{LsD}_{5 \%}$ \\
\hline \multirow{4}{*}{ phacelia } & no fertilisation & $73.7 \pm 13.8 \mathrm{Ac}^{*}$ & $30.1 \pm 4.7 \mathrm{Aa}$ & $31.7 \pm 5.4 \mathrm{Aa}$ & $103.4 \pm 21.7 \mathrm{Ad}$ & $47.8 \pm 3.1 \mathrm{Ab}$ & 57.3 & 21.9 \\
\hline & $\begin{array}{l}\text { with } 50 \mathrm{~kg} \mathrm{~N} \mathrm{ha}^{-1} \\
\text { fertiliser }\end{array}$ & $164.4 \pm 11.4 \mathrm{Bc}$ & $118.2 \pm 12.0 \mathrm{Bb}$ & $86.1 \pm 10.7 \mathrm{Ba}$ & $214.1 \pm 29.7 \mathrm{Bd}$ & $97.9 \pm 3.8 \mathrm{Bab}$ & 136.1 & 29.2 \\
\hline & $\begin{array}{l}\text { change in nutrient content } \\
(\%)\end{array}$ & $223 \%$ & $393 \%$ & $271 \%$ & $207 \%$ & $205 \%$ & $260 \%$ & \\
\hline & $\mathrm{LSD}_{5 \%}$ & 28.7 & 20.7 & 19.2 & 59.0 & 7.9 & & \\
\hline \multirow{4}{*}{ mustard } & no fertilisation & $88.1 \pm 17.5 \mathrm{Ab}$ & $33.6 \pm 8.7 \mathrm{Aa}$ & $85.2 \pm 18.9 \mathrm{Ab}$ & $96.6 \pm 22.4 \mathrm{Ab}$ & $47.7 \pm 2.7 \mathrm{Aa}$ & 70.2 & 28.7 \\
\hline & $\begin{array}{l}\text { with } 50 \mathrm{~kg} \mathrm{~N} \mathrm{ha}^{-1} \\
\text { fertiliser }\end{array}$ & $188.0 \pm 6.7 \mathrm{Bb}$ & $138.8 \pm 21.0 \mathrm{Ba}$ & $283.2 \pm 42.4 \mathrm{Bc}$ & $220.3 \pm 9.8 \mathrm{Bb}$ & $103.0 \pm 3.1 \mathrm{Ba}$ & 186.7 & 39.8 \\
\hline & $\begin{array}{l}\text { change in nutrient content } \\
(\%)\end{array}$ & $213 \%$ & $413 \%$ & $333 \%$ & $228 \%$ & $216 \%$ & $281 \%$ & \\
\hline & $\mathrm{LSD}_{5 \%}$ & 30.0 & 36.5 & 74.4 & 39.2 & 6.6 & & \\
\hline \multirow{4}{*}{$\begin{array}{l}\text { oilseed } \\
\text { radish }\end{array}$} & no fertilisation & $64.1 \pm 12.6 \mathrm{Ab}$ & $31.1 \pm 6.8 \mathrm{Aa}$ & $57.4 \pm 9.4 \mathrm{Ab}$ & $103.3 \pm 6.5 \mathrm{Ac}$ & $51.5 \pm 3.9 \mathrm{Ab}$ & 61.5 & 15.3 \\
\hline & $\begin{array}{l}\text { with } 50 \mathrm{~kg} \mathrm{~N} \mathrm{ha}^{-1} \\
\text { fertiliser }\end{array}$ & $174.9 \pm 9.0 \mathrm{Bb}$ & $127.0 \pm 13.7 \mathrm{Ba}$ & $172.0 \pm 33.1 \mathrm{Bb}$ & $180.7 \pm 5.8 \mathrm{Bb}$ & $102.7 \pm 2.2 \mathrm{Ba}$ & 151.5 & 30.5 \\
\hline & $\begin{array}{l}\text { change in nutrient content } \\
(\%)\end{array}$ & $273 \%$ & $409 \%$ & $299 \%$ & $175 \%$ & $199 \%$ & $271 \%$ & \\
\hline & $\mathrm{LSD}_{5 \%}$ & 24.9 & 24.4 & 55.2 & 13.9 & 7.2 & & \\
\hline
\end{tabular}

*Capital letter: post hoc test between treatments

Small letter: post hoc test between years 
As an average of the five years of the experiment the amount of absorbed nitrogen per hectare increased to $2.81 \%$ the amount fixed without added nitrogen. The application of $50 \mathrm{~kg} / \mathrm{ha}$ nitrogen enabled the utilisation of an additional $66.5 \mathrm{~kg}$ nitrogen active ingredient. Of the plants used in the experiment mustard contained the largest amount of nitrogen. Its efficiency in fixing nitrogen had been observed by Baggs et al. (2000) as well. The growth of mustard sown among short-day plants remained vegetative, producing a substantial mass of foliage, and it is the very leaves of the plant that can store the largest quantities of nitrogen (Chaves et al., 2004).

In the case of oilseed radish the active ingredient uptake increased by 2.7 times as an average over five years, i.e. the delivery of $50 \mathrm{~kg} / \mathrm{ha}$ nitrogen enabled the uptake of an additional $40.0 \mathrm{~kg} / \mathrm{ha}$. Like mustard, oilseed radish also produced a large mass of foliage, and of all plant organs leaves contain the largest quantities of nitrogen (Rogasik et al., 1992; Muller et al., 1988).

The per-hectare $\mathrm{P}_{2} \mathrm{O}_{5}$ contents are illustrated by the figures presented in Table 7. The $\mathrm{P}_{2} \mathrm{O}_{5}$ content of phacelia increased to 2.36, that of mustard grew to 2.29 times and that of oilseed radish increased to 2.09 times the amounts measured on plots without fertiliser, as an average of the five years of the experiment. The application of nitrogen fertiliser enabled, as an average of five years, the uptake of an additional $26.6 \mathrm{~kg}$ of $\mathrm{P}_{2} \mathrm{O}_{5}$ in the case of phacelia, while the increase in the case of mustard and oilseed radish amounted to $27.0 \mathrm{~kg}$ and $30.4 \mathrm{~kg}$, respectively. The increase in the per-hectare amount of $\mathrm{P}_{2} \mathrm{O}_{5}$ absorbed by plants is explained by Liebig's minimum law.

The per-hectare $\mathrm{K}_{2} \mathrm{O}$ contents are illustrated by the figures presented in Table 8. The $\mathrm{K}_{2} \mathrm{O}$ content of phacelia increased to 2.13 , that of mustard grew to 2.29 times and that of oilseed radish increased to 1.95 times the amounts measured on plots without fertiliser, as an average of the five years of the experiment. The application of nitrogen fertiliser enabled, as an average of five years, the uptake of an additional $88.1 \mathrm{~kg}$ of $\mathrm{P}_{2} \mathrm{O}_{5}$ in the case of phacelia, while the increase in the case of mustard and oilseed radish amounted to $102.9 \mathrm{~kg}$ and $69.2 \mathrm{~kg}$, respectively.

Significant differences between the biomass increase caused by the application of one unit $(1 \mathrm{~kg})$ of nitrogen active ingredient and the crop-year effect could be detected in all cases (Table 9). The adding of one unit of nitrogen resulted in a significant increase in the biomass produced. One $\mathrm{kg}$ of nitrogen active ingredient increased the green mass by $412.5 \mathrm{~kg}$ and the dry mass by $37.9 \mathrm{~kg}$ as an average of the five years of the experiment. In the case of mustard the green mass grew by $431.4 \mathrm{~kg}$, the dry mass increased by $59.1 \mathrm{~kg}$, while in the case of oilseed radish the corresponding figures were $386.7 \mathrm{~kg}$ and $34.1 \mathrm{~kg}$.

The crop-year effect did not always have a statistically proven impact on the perhectare NPK uptake increase caused by the application of a unit of fertiliser active ingredient (Table 10). The quantity of nutrients absorbed increased regardless of the amount and distribution of precipitation. One kilogram of nitrogen active ingredient enabled, the uptake of an additional $1.6 \mathrm{~kg}$ of nitrogen in the case of phacelia, $2.3 \mathrm{~kg}$ in the case of mustard and $1.8 \mathrm{~kg}$ in the case of oilseed radish, as an average of the period between 2007 and 2011. This is of particular importance in view of the fact that the soil of the experiment site has a low nitrogen content. The added nitrogen increased the availability of $\mathrm{P}_{2} \mathrm{O}_{5}$ as well, as each $\mathrm{kg}$ of added nitrogen resulted in a $0.5 \mathrm{~kg} .0 .5 \mathrm{~kg}$ and $0.6 \mathrm{~kg}$ of additional $\mathrm{P}_{2} \mathrm{O}_{5}$ uptake in phacelia, mustard and oilseed radish, respectively. Each $\mathrm{kg}$ of added active ingredient resulted in an $1.8 \mathrm{~kg}, 2.1 \mathrm{~kg}$ and $1.4 \mathrm{~kg}$ additional $\mathrm{K}_{2} \mathrm{O}$ uptake in phacelia, mustard and oilseed radish, respectively. 
Table 7. Effect of different nutrient levels on the uptake of $\mathrm{P}_{2} \mathrm{O}_{5}$ amount of green manure plants ( $\mathrm{kg}$ ha ${ }^{-1}$ ) (Gödöllö, 2007-2011)

\begin{tabular}{|c|c|c|c|c|c|c|c|c|}
\hline treatment & & 2007 & 2008 & 2009 & 2010 & 2011 & mean & $\mathrm{LSD}_{5 \%}$ \\
\hline \multirow{4}{*}{ phacelia } & no fertilisation & $39.2 \pm 16.3 \mathrm{Abc}^{*}$ & $13.9 \pm 2.9 \mathrm{Aab}$ & $8.7 \pm 2.4 \mathrm{Aa}$ & $26.0 \pm 6.2 \mathrm{Ab}$ & $29.0 \pm 1.8 \mathrm{Abc}$ & 23.4 & 14.6 \\
\hline & with $50 \mathrm{~kg} \mathrm{~N} \mathrm{ha}^{-1}$ fertiliser & $61.0 \pm 4.1 \mathrm{Bc}$ & $43.5 \pm 3.9 \mathrm{Bb}$ & $23.2 \pm 3.7 \mathrm{Ba}$ & $64.8 \pm 7.7 \mathrm{Bc}$ & $57.4 \pm 2.2 \mathrm{Bc}$ & 50.0 & 8.5 \\
\hline & $\begin{array}{l}\text { change in nutrient content } \\
(\%)\end{array}$ & $156 \%$ & $313 \%$ & $265 \%$ & $198 \%$ & $198 \%$ & $236 \%$ & \\
\hline & $\mathrm{LSD}_{5 \%}$ & 26.9 & 7.8 & 7.2 & 15.8 & 4.6 & & \\
\hline \multirow{4}{*}{ mustard } & no fertilisation & $27.3 \pm 4.7 \mathrm{Abc}$ & $12.7 \pm 2.8 \mathrm{Aa}$ & $22.7 \pm 7.1 \mathrm{Ab}$ & $30.9 \pm 3.6 \mathrm{Ac}$ & $25.5 \pm 3.0 \mathrm{Abc}$ & 23.4 & 8.2 \\
\hline & with $50 \mathrm{~kg} \mathrm{~N}^{-1}$ fertiliser & $46.2 \pm 1.5 \mathrm{Bb}$ & $32.3 \pm 4.3 \mathrm{Ba}$ & $61.8 \pm 9.3 \mathrm{Bc}$ & $62.7 \pm 9.4 \mathrm{Bc}$ & $49.0 \pm 1.5 \mathrm{Bb}$ & 50.4 & 11.4 \\
\hline & $\begin{array}{l}\text { change in nutrient content } \\
(\%)\end{array}$ & $169 \%$ & $254 \%$ & $272 \%$ & $203 \%$ & $192 \%$ & $229 \%$ & \\
\hline & $\mathrm{LSD}_{5 \%}$ & 7.9 & 8.2 & 18.7 & 16.1 & 5.4 & & \\
\hline \multirow{4}{*}{$\begin{array}{l}\text { oilseed } \\
\text { radish }\end{array}$} & no fertilisation & $38.8 \pm 2.8 \mathrm{Ab}$ & $18.3 \pm 1.8 \mathrm{Aa}$ & $17.3 \pm 0.5 \mathrm{Aa}$ & $35.1 \pm 3.3 \mathrm{Ab}$ & $50.5 \pm 9.3 \mathrm{Ac}$ & 32.0 & 8.5 \\
\hline & with $50 \mathrm{~kg} \mathrm{~N}^{-1}$ fertiliser & $51.9 \pm 4.7 \mathrm{Bb}$ & $34.1 \pm 5.5 \mathrm{Ba}$ & $58.4 \pm 12.1 \mathrm{Bb}$ & $65.1 \pm 9.1 \mathrm{Bb}$ & $102.7 \pm 2.2 \mathrm{Bc}$ & 62.4 & 13.8 \\
\hline & $\begin{array}{l}\text { change in nutrient content } \\
(\%)\end{array}$ & $134 \%$ & $186 \%$ & $338 \%$ & $185 \%$ & $203 \%$ & $209 \%$ & \\
\hline & $\mathrm{LSD}_{5 \%}$ & 8.8 & 9.3 & 19.4 & 15.6 & 15.3 & & \\
\hline
\end{tabular}

Small letter: post hoc test between years 
Table 8. Effect of different nutrient levels on the uptake of $\mathrm{K}_{2} \mathrm{O}$ amount of green manure plants ( $\mathrm{kg} \mathrm{ha} \mathrm{a}^{-1}$ ) (Gödöllö, 2007-2011)

\begin{tabular}{|c|c|c|c|c|c|c|c|c|}
\hline treatm & & 2007 & 2008 & 2009 & 2010 & 2011 & mean & $\mathrm{LSD}_{5 \%}$ \\
\hline \multirow{4}{*}{ phacelia } & \multirow{3}{*}{$\begin{array}{l}\text { no fertilisation } \\
\text { with } 50 \mathrm{~kg} \mathrm{~N} \mathrm{ha}{ }^{-1} \\
\text { fertiliser } \\
\text { change in nutrient } \\
\text { content }(\%)\end{array}$} & $190.8 \pm 9.9 \mathrm{Ad}^{*}$ & $75.2 \pm 4.9 \mathrm{Ab}$ & $34.0 \pm 3.7 \mathrm{Aa}$ & $111.3 \pm 17.0 \mathrm{Ac}$ & $92.3 \pm 10.5 \mathrm{Abc}$ & 100.7 & 18.8 \\
\hline & & $251.7 \pm 15.6 \mathrm{Bcd}$ & $179.5 \pm 17.6 \mathrm{Bb}$ & $97.8 \pm 23.6 \mathrm{Ba}$ & $219.4 \pm 24.1 \mathrm{Bc}$ & $195.8 \pm 7.7 \mathrm{Bbc}$ & 188.8 & 34.1 \\
\hline & & $132 \%$ & $239 \%$ & $287 \%$ & $197 \%$ & $212 \%$ & $213 \%$ & \\
\hline & \multirow{2}{*}{$\begin{array}{l}\mathrm{LSD}_{5 \%} \\
\text { no fertilisation }\end{array}$} & 29.7 & 29.3 & 38.3 & 47.3 & 20.8 & & \\
\hline \multirow{3}{*}{ mustard } & & $156.4 \pm 24.7 \mathrm{Ac}$ & $52.3 \pm 18.6 \mathrm{Aa}$ & $91.6 \pm 23.4 \mathrm{Ab}$ & $98.7 \pm 19.2 \mathrm{Ab}$ & $73.1 \pm 6.6 \mathrm{Aab}$ & 94.4 & 35.6 \\
\hline & \multirow{2}{*}{$\begin{array}{l}\text { with } 50 \mathrm{~kg} \mathrm{~N} \mathrm{ha}^{-1} \\
\text { fertiliser } \\
\text { change in nutrient } \\
\text { content }(\%)\end{array}$} & $253.8 \pm 23.4 \mathrm{Bcd}$ & $183.2 \pm 33.2 \mathrm{Bab}$ & $218.4 \pm 27.0 \mathrm{Bb}$ & $169.3 \pm 16.0 \mathrm{Ba}$ & $161.7 \pm 4.8 \mathrm{Ba}$ & 197.3 & 42.0 \\
\hline & & $162 \%$ & $350 \%$ & $238 \%$ & $172 \%$ & $221 \%$ & $229 \%$ & \\
\hline \multirow{4}{*}{$\begin{array}{l}\text { oilseed } \\
\text { radish }\end{array}$} & & $\begin{array}{r}54.6 \\
121.8 \pm 6.6 \mathrm{Ad}\end{array}$ & $\begin{array}{r}61.0 \\
58.0 \pm 2.7 \mathrm{Aa}\end{array}$ & $\begin{array}{r}57.3 \\
62.1 \pm 6.4 \mathrm{Aa}\end{array}$ & $\begin{array}{r}40.0 \\
111.1 \pm 3.4 \mathrm{Ac}\end{array}$ & $\begin{array}{r}13.2 \\
81.0 \pm 4.4 \mathrm{Ab}\end{array}$ & 86.8 & 9.1 \\
\hline & \multirow{3}{*}{$\begin{array}{l}\text { no fertilisation } \\
\text { with } 50 \mathrm{~kg} \mathrm{~N} \mathrm{ha}^{-1} \\
\text { fertiliser } \\
\text { change in } \\
\text { content (\%) } \\
\text { LSD }_{5 \%}\end{array}$} & $178.9 \pm 13.8 \mathrm{Bb}$ & $126.8 \pm 27.2 \mathrm{Ba}$ & $175.6 \pm 42.1 \mathrm{Bab}$ & $132.4 \pm 17.9 \mathrm{Bab}$ & $166.4 \pm 19.7 \mathrm{Bab}$ & 156.0 & 47.5 \\
\hline & & $147 \%$ & $219 \%$ & $283 \%$ & $119 \%$ & $205 \%$ & $195 \%$ & \\
\hline & & 24.5 & 43.9 & 68.2 & 29.4 & 32.4 & & \\
\hline
\end{tabular}

*Capital letter: post hoc test between treatments

Small letter: post hoc test between years 
Table 9. Specific biomass increasing effect of $1 \mathrm{~kg}$ additional $\mathrm{N}\left(\mathrm{kg} \mathrm{ha}^{-1}\right)$

\begin{tabular}{|c|c|c|c|c|c|c|c|c|}
\hline plants & biomass & 2007 & 2008 & 2009 & 2010 & 2011 & mean & $\mathrm{LSD}_{5 \%}$ \\
\hline \multirow{2}{*}{ phacelia } & $\begin{array}{l}\text { green } \\
\text { mass }\end{array}$ & $336.1 \pm 69.0 \mathrm{ab}$ & $575.8 \pm 114.0 \mathrm{~d}$ & $237.5 \pm 57.3 \mathrm{a}$ & $490.3 \pm 90.4 \mathrm{c}$ & $423.0 \pm 37.2 b c$ & 412.5 & 111.9 \\
\hline & dry mass & $26.2 \pm 12.2 \mathrm{a}$ & $37.4 \pm 4.4 \mathrm{a}$ & $29.1 \pm 4.8 \mathrm{a}$ & $58.2 \pm 18.2 b$ & $38.5 \pm 3.8 \mathrm{a}$ & 37.9 & 14.8 \\
\hline \multirow{2}{*}{ mustard } & $\begin{array}{l}\text { green } \\
\text { mass }\end{array}$ & $268.5 \pm 36.8 \mathrm{a}$ & $487.3 \pm 56.9 \mathrm{~d}$ & $633.3 \pm 38.8 \mathrm{e}$ & $434.2 \pm 12.6 \mathrm{c}$ & $333.6 \pm 25.1 b$ & 431.4 & 53.1 \\
\hline & dry mass & $38.9 \pm 9.4 \mathrm{a}$ & $48.1 \pm 7.6 \mathrm{a}$ & $93.0 \pm 13.1 \mathrm{c}$ & $74.9 \pm 4.2 b$ & $40.7 \pm 2.9 \mathrm{a}$ & 59.1 & 11.9 \\
\hline \multirow{2}{*}{$\begin{array}{l}\text { oilseed } \\
\text { radish }\end{array}$} & $\begin{array}{c}\text { green } \\
\text { mass }\end{array}$ & $329.8 \pm 20.9 a$ & $356.1 \pm 60.2 \mathrm{ab}$ & $480.8 \pm 102.6 \mathrm{c}$ & $349.0 \pm 6.8 \mathrm{ab}$ & $417.7 \pm 7.9 \mathrm{~b}$ & 386.7 & 77.5 \\
\hline & dry mass & $23.1 \pm 4.2 \mathrm{a}$ & $30.2 \pm 9.6 \mathrm{a}$ & $63.0 \pm 14.6 \mathrm{~b}$ & $24.8 \pm 3.7 \mathrm{a}$ & $29.5 \pm 0.5 \mathrm{a}$ & 34.1 & 11.7 \\
\hline
\end{tabular}


Table 10. Specific NPK content increasing effect of $1 \mathrm{~kg}$ additional $\mathrm{N}\left(\mathrm{kg} \mathrm{ha}^{-1}\right)$

\begin{tabular}{ccccccccc}
\hline plants & $\mathrm{NPK}$ & 2007 & 2008 & 2009 & 2010 & 2011 & mean & LSD $_{5 \%}$ \\
\hline \multirow{5}{*}{ phacelia } & $\mathrm{N}$ & $1.8 \pm 0.3$ & $1.8 \pm 0.3$ & $1.1 \pm 0.3$ & $2.2 \pm 1.0$ & $1.0 \pm 0.1$ & 1.6 & $\mathrm{~ns}$ \\
& $\mathrm{P}_{2} \mathrm{O}_{5}$ & $0.4 \pm 0.2 \mathrm{a}$ & $0.6 \pm 0.1 \mathrm{a}$ & $0.3 \pm 0.1 \mathrm{a}$ & $0.8 \pm 0.2 \mathrm{a}$ & $0.6 \pm 0.03 \mathrm{a}$ & 0.5 & 0.8 \\
& $\mathrm{~K}_{2} \mathrm{O}$ & $1.2 \pm 0.4 \mathrm{a}$ & $2.1 \pm 0.4 \mathrm{~b}$ & $1.3 \pm 0.5 \mathrm{a}$ & $2.2 \pm 0.8 \mathrm{~b}$ & $2.1 \pm 0.2 \mathrm{~b}$ & 1.8 & 0.5 \\
& $\mathrm{~N}$ & $2.0 \pm 0.3 \mathrm{~b}$ & $2.1 \pm 0.4 \mathrm{~b}$ & $4.0 \pm 1.2 \mathrm{~d}$ & $2.5 \pm 0.4 \mathrm{c}$ & $1.1 \pm 0.1 \mathrm{a}$ & 2.3 & 0.2 \\
mustard & $\mathrm{P}_{2} \mathrm{O}_{5}$ & $0.4 \pm 0.1$ & $0.4 \pm 0.1$ & $0.8 \pm 0.3$ & $0.6 \pm 0.2$ & $0.5 \pm 0.1$ & 0.5 & $\mathrm{~ns}$ \\
& $\mathrm{~K}_{2} \mathrm{O}$ & $1.9 \pm 0.8 \mathrm{~b}$ & $2.6 \pm 0.5 \mathrm{c}$ & $2.5 \pm 0.9 \mathrm{c}$ & $1.4 \pm 0.1 \mathrm{a}$ & $1.8 \pm 0.1 \mathrm{~b}$ & 2.1 & 0.2 \\
& $\mathrm{~N}$ & $2.2 \pm 0.2$ & $1.9 \pm 04$ & $2.3 \pm 0.6$ & $1.5 \pm 0.2$ & $1.0 \pm 0.1$ & 1.8 & $\mathrm{~ns}$ \\
oilseed radish & $\mathrm{P}_{2} \mathrm{O}_{5}$ & $0.3 \pm 0.1$ & $0.3 \pm 01$ & $0.8 \pm 0.2$ & $0.6 \pm 0.1$ & $1.0 \pm 0.1$ & 0.6 & $\mathrm{~ns}$ \\
& $\mathrm{~K}_{2} \mathrm{O}$ & $1.1 \pm 0.4 \mathrm{ab}$ & $1.4 \pm 0.6 \mathrm{~b}$ & $2.3 \pm 1.0 \mathrm{c}$ & $0.4 \pm 0.4 \mathrm{a}$ & $1.7 \pm 0.3 \mathrm{bc}$ & 1.4 & 0.8 \\
\hline
\end{tabular}

\section{Conclusions}

Each of the three plant species involved in the experiment was suitable for use as green manure under the given unfavourable site conditions, fulfilling their roles in terms of soil protection and organic matter conserving. In regard to the per-hectare biomass and chemical composition, particularly in view of the uptake of nitrogen, the cruciferous mustard and oilseed radish were found to perform better than phacelia.

The $50 \mathrm{~kg} / \mathrm{ha}$ nitrogen active ingredient made a significant contribution to the increase in the total amount of biomass produced and improvement in its chemical composition, while without added nitrogen the crop was badly affected by what is known as pentosan effect. The application of nitrogen fertiliser multiplied the perhectare nitrogen content in each of the three plant species. The added nitrogen also greatly facilitated the uptake of phosphorous and potassium.

After the delivery of $50 \mathrm{~kg} / \mathrm{ha}$ nitrogen each of the three plant species produced a stable green mass with substantial amounts NPK absorbed, but without added nitrogen the poorly endowed site could not always produce the amount that would have been considered as adequate. It is concluded from the results of the experiment that when growing second crops for green manure at the given site nitrogen should always be applied but when the straw is left on the field to be incorporated into the soil after the harvest of cereal crops, the application of nitrogen is indispensable.

Acknowledgements. Research Centre of Excellence - 8526-5/2014/TUDPOL

\section{REFERENCES}

[1] Allison, M. F., Armstrong, M. J., Jaggard, K. W., Todd, A. D. (1998a.): Integration of nitrate cover crops into sugarbeet (Beta vulgaris) rotations. I. Management and effectiveness of nitrate cover crops. - Journal of Agricultural Science 130: 53-60.

[2] Allison, M. F., Armstrong M. J., Jaggard, K. W., Todd, A. D. (1998b): Integration of nitrate cover crops into sugarbeet (Beta vulgaris) rotations. II. Effect of cover crops on growth, yield and $\mathrm{N}$ requirement of sugarbeet. - Journal of Agricultural Science 130: 6167. 
[3] Allison, M. F., Armstrong, M. J. (1992): The integration of cover crops into sugar beet (Beta vulgaris) rotations. - Aspects of Applied Biology 30: 301-308.

[4] Antal, J. (2000): Növénytermesztők zsebkönyve (Crop producers' pocket book). Mezőgazda Kiadó. Budapest.

[5] Asagi, N., Ueno, H. (2009): Nitrogen dynamics in paddy soil applied with various ${ }^{15} \mathrm{~N}$ labelled green manures. - Plant Soil 322: 251-262.

[6] Baggs, E. M., Watson, C. A., Rees, R. M. (2000): The fate of nitrogen from incorporated cover crop and green manure residues. - Nutrient Cycling in Agroecosystems 56: 153163.

[7] Bialy, Z., Oleszek, W., Lewis, J., Fenwick, G. R. (1990): Allelopathic potential of glucosinolates (mustard oil glycosides) and their degradation products against wheat. Plant Soil 129: 277-281.

[8] Blazewick-Wozniak, M., Wach, D. (2012): The fertiliser value of summer catch crops preceding vegetables and its variation in the changing weather conditions. - Acta Scientinarium Polonorum Hortorum Cultus 11(3): 101-116.

[9] Boydston, R. A., Hang, A. (1995): Rapeseed (Brassica napus) green manure crop suppresses weeds in potato (Solanum tuberosum). - Weed Technology 9: 669-675.

[10] Bradow, J. M. (1991): Relationships between chemical structure and inhibitory activity of $\mathrm{C}_{6}$ through $\mathrm{C}_{9}$ volatiles emitted by plant residues. - Journal of Chemistry Ecology 17: 2193-2212.

[11] Brown, P. D., Mora M. J. (1995): Gluosinolate-containing plant tissues as bioherbicides. Journal of Agricultural and Food Chemistry 43: 3070-3074.

[12] Brown, P. D., Morra M. J., Mccaffrey, J. P., Auld, D. L., Williams, L., I. (1991): Allelochemicals produced during glucosinolate degradation in soil. - Journal of Chemistry Ecology 17: 2021-2034.

[13] Cadisch, G., Giller, K. E. (1997): Driven by Nature: Plant Litter Quality and Decomposition. - Wallingford: CAB International. 409.

[14] Catt, J.A., Christian, D.G., Goss, M.J., Harris, G.C., Howse, K.R. (1992): Strategies to reduce nitrate leaching by crop rotation, minimal cultivation and straw incorporation in the Brimstone Farm Experiment, Oxfordshire. - Aspects of Applied Biology 30: 255-262.

[15] Chaves, B., Neve, S., Hofman, G., Boeckx, P., Cleemput, O. (2004): Nitrogen mineralization of vegetable root residues and green manures as related to their (bio)chemical composition. - European Journal of Agronomy 21(2): 161-170.

[16] Clark, A. J., Decker, A. M., Meisinger, J. J., McIntosh, M. S. (1997a): Kill date of vetch, rye, and a vetch-rye mixture: I. Cover crop and corn nitrogen. - Agronomy Journal 89: 427-434.

[17] Clark, A. J., Decker, A. M., Meisinger, J. J., McIntosh, M. S. (1997b): Kill date of vetch, rye, and a vetch-rye mixture II. Soil moisture and corn yield. - Agronomy Journal 89: 434-441.

[18] Collins, H. P., Delgado, J. A., Alva, A. K., Follett, R. F. (2007): Use of nitrogen-15 isotopic techniques to estimate nitrogen cycling from a mustard cover crop to potatos. Agronomy Journal 99: 27-35.

[19] Croft, K. P. C., Juttner, F., Slusarenko, A. J. (1993): Volatile products of the lipoxygenase pathway evolved from Phaseolus vulgaris (L.) leaves inoculated with Pseudomonas syringae pv phaseolicola. - Plant Physiology 101:13-24.

[20] Deng, W., Hamilton-Kemp, T. R., Nielsen, M. T., Andersen, R. A., Collins, G. B., Hildebrand, D. F. (1993): Effects of six-carbon aldehydes and alcohols on bacterial proliferation. - Journal of Agricultural and Food Chemistry 41: 506-510.

[21] Derpsch, R., Sidiras, N., Roth, C. H. (1986): Results of studies made from 1977 to 1984 to control erosion by cover crops and no-tillage techniques in Paraná, Brazil. - Soil and Tillage Research 8: 253-263. 
[22] Dhima, K. V., Vasilakoglou, I. B., Gatsis, T. D., Panou-Philotheou, E., Eleftherohorinos, I. G. (2009): Effects of aromatic plants incorporated as green manure on weed and maize development. - Field Crops Research 110: 235-241.

[23] Foucault, Y., Lévéque, T., Xiong, T., Schreck, E., Austruy, A., Shahid, M., Dumat, C. (2013): reen manure plants for remediation of soils polluted by metals and metalloids (Ecotoxicity and human bioavailability assessment. - Chemosphere. 93. 7. 1430-1435.

[24] Füleky, Gy. (1999): Tápanyag-gazdálkodás (Nutrient management). - Mezőgazda Kiadó. Budapest.

[25] Gardner, H. W., Dornbos, D. L., Jr., Desjardins, A. E. (1990): Hexanal, trans 2-hexenal, and trans-2-noncnal inhibit soybean, Glycine max, seed germination. - Journal of Agricultural and Food Chemistry 38: 1316-1320.

[26] Grossman, J. (1993): Brassica alternatives to herbicides and soil fumigants. Integrated Pest Management Practicum. 15.1- 10.

[27] Jackson, L. E., Wyland, L. J., Stivers, L. J. (1993): Winter cover crops to minimise nitrate losses in intensive lettuce production. - Journal of Agricultural Science 121: 55-62.

[28] Kahnt, G. (1981): Gründüngung. - DLG-Verlag. Frankfurt.

[29] Kara, E., Penezoglu, M. (2000): The effect of green manuring on soil organic content and soil biological avctivity. Anadolu. 10. 1. 73-86.

[30] Késmárki, I., Petróczki, F. (2003): Komposztálás-zöldtrágyázás (Composting, green manuring). - Agro Napló 7(7): 11-13.

[31] Kim, K. R., Owens, G., Kwon, S. I. (2010): Influence of Indian mustard (Brassica juncea) on rhizosphere soil solution chemistry in long-term contaminated soils: a rhizobox study. - Journal of Environmental Science 22: 98-105.

[32] Lazzeri, L., Tacconi,R., Palmieri, S. (1993): In vitro activity of some glucosinolates and their reaction products toward a population of the nematode Heterodera schachtii. Journal of Agricultural and Food Chemistry 41: 825-829.

[33] Martinez, J., Guiraud, G. (1990): A lysimeter study of the effects of a ryegrass catch crop during a winter wheat/maize rotation, on nitrate leaching and on the following crop. Journal of Soil Science 41: 5-16.

[34] Máté, A. (2005): Növénytermesztési Tanüzem (Cropping study farm). Tanulmány. Gödöllő.

[35] Mayton, H. S., Oliver, C., Vaughn, S. F., Loria, R. (1996): Correlation of fungicidal activity of Brassica species with allyl isothiocyanate production in macerated leaf tissue. Phytopathology 86: 267-271.

[36] MÉM-NAK (1979): A mütrágyázás üzemi számítási módszere. MÉM, Budapest

[37] Mojtahedi, H., Santo, G. S., Hang, A., Wilson, J. H. (1991): Suppression of root-knot nematode populations with selected rapeseed cultivars as green manure. - Journal of Nematology 23: 170-174.

[38] Mojtahedi, H., Santo, G. S., Wilson, J. H., Hang, A. (1993): Managing Melodogyne chitwoodi on potato with rapeseed as green manure. - Plant Disease 77: 42-46.

[39] Muelichen, A. M., Rand, R. E., Parke, J. L. (1990): Evaluation of crucifer green manuresfor controlling Aphanomyces root rot of peas. - Plant Disease 74: 651-654.

[40] Muller, J. C., Denys, D., Morlet, G., Mariotta, A. (1988): Influence of catch crops on mineral nitrogen leaching and its subsequent plant use, pp. 8598. - In: Jenkinson, D.S., Smith, K.A. (eds.) Nitrogen efficiency in agricultural soils, vol. 2. Elsevier Applied Science, New York.

[41] Papavizas, G. C., Lewis, J. A. (1971): Effect of amendments and fungicides on Aphanomycesroot rot of peas. - Phytopathology 61: 215-220.

[42] Papavizas, G. C. (1966): Suppression of Aphanomyces root rot of peas by cruciferous soil amendments. - Phytopathology 56: 1071-1075.

[43] Ramirez-Villapudua, J., Munecke., D. E. (1988): Effect of solar heating and soil amendments of cruciferous residues on Fusarium oxysporum $\mathrm{f}$. sp. conglutinans and other organisms. - Phytopathology 78: 289-295. 
[44] Rogasik, J., Smukalski, M., Obenauf, S. (1992): Cover crops on sandland in Germany: Husbandry and fate of nitrogen. - Aspects of Applied Biology 30: 309-316.

[45] Richards, I. R., Wallace, P.A., Turner, I. D. S. (1996): A comparsion of six cover crop types in terms of nitrogen uptake and effect on response to nitrogen by a subsequent spring barley crop. - Journal of Agricultural Science 127: 441-449.

[46] Stefanovits, P. (1999a): Főtipusok, típusok és altípusok (Main types, types and subtypes). - In: Stefanovits, P., Filep, Gy., Füleky, Gy.: Talajtan. Mezőgazda Kiadó. Budapest.

[47] Stefanovits, P. (1999b): A tájak talajviszonyai (Soil conditions in Hungary's regions). In: Stefanovits, P., Filep, Gy., Füleky, Gy.: Talajtan. Mezőgazda Kiadó. Budapest.

[48] Stivers-Young, L. (1998): Growth, Nitrogen Accumulation, and Weed Suppression by Fall Cover Crops Following Early Harvest of Vegetables. - Hortscience 33(1): 60-63.

[49] Thorup-Kristensen, K. (1993): The effect of nitrogen catch crops on the nitrogen nutrition of a succeeding crop 1. Effects through mineralisation and pre-emptive competition. Acta Agriculturae Scandinavica Section B, Soil and Plant Science 43:74-81.

[50] Vaughan, J. D., Evanylo, G. K. (1998): Corn response to cover crop species, spring dessication time, and residue management. - Agronomy Journal 90:536-544.

[51] Vaughn, S. F., Boydston, R. A. (1997): Volatile allelochemicals released by Crucifer green manures. - Journal of Chemical Ecology 23(9): 2107-2116.

[52] Williams, L., Morra, M. J., Brown, P. D., McCaffrey, J. P. (1993): Toxicity of allyl.isothiocyanate-amended soil to Limonius californicus (Mann.) (Coleoptera: Elateridae) wireworms. - Journal of Chemical Ecology 19:1033-1046.

[53] Zhang, M. K., Fang, L. P. (2007): Effect of tillage, fertiliser and green manure cropping on soil quality at an abandoned brick making site. - Soil and Tillage Research 93:87-93.

\section{ELECTRONIC APPENDIX}

This article has an electronic appendix with basic data. 